DOI: $10.6060 / \mathrm{mhc} 170520 \mathrm{~g}$

\title{
Liquid Silyl Derivative of beta-Cyclodextrin
}

\author{
Askar K. Gatiatulin, ${ }^{\mathrm{a}}{ }^{@}$ Marat A. Ziganshin, ${ }^{\mathrm{a}}$ Galina I. Kurochkina, ${ }^{\mathrm{b}}$ Artem V. Popkov, ${ }^{\mathrm{b}}$ \\ Mikhail K. Grachev, ${ }^{\mathrm{b}}$ and Valery V. Gorbatchuk ${ }^{\mathrm{a}}$ \\ ${ }^{a}$ A.M. Butlerov Institute of Chemistry, Kazan Federal University, 420008 Kazan, Russia \\ ${ }^{\mathrm{b}}$ Institute of Biology and Chemistry, Moscow State Pedagogical University, 119021 Moscow, Russia \\ ${ }^{\circledR}$ Corresponding authorE-mail: agatiatu@kpfu.ru
}

\begin{abstract}
Per-6-O-(tert-butyl)(diphenyl)silyl- $\beta$-cyclodextrin was found to form metastable liquid phase, which is unusual for cyclodextrin mono-derivatives under ambient conditions. Also, it can exist in a solid amorphous state as a stable molecular glass. Conditions and parameters of phase transitions between crystal, glassy and liquid forms were determined. The studied compound is soluble in various solvents. Crystallization from its solutions and overcooled melt results in formation of two different polymorphs. The liquid mono-derivative of beta-cyclodextrin is amphiphilic and preferable for application in solutions, in pure form or even as a solvent for substrates with various structures.
\end{abstract}

Keywords: Cyclodextrin, silyl derivatives, polymorphism, molecular glass, thermal analysis, X-ray powder diffraction.

\section{Жидкое силильное производное бета-циклодекстрина}

\author{
А. К. Гатиатулин, ${ }^{a}$ М. А. Зиганшин, ${ }^{a}$ Г. И. Курочкина, ${ }^{\text {b }}$ А. В. Попков, ${ }^{\text {b }}$ \\ M. К. Грачев, ${ }^{\mathrm{b}}$ B. В. Горбачук ${ }^{\mathrm{a}}$
}

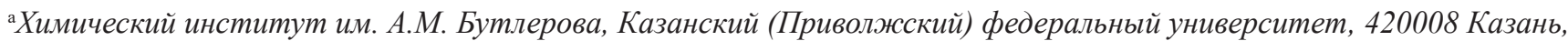
Россия

${ }^{\mathrm{b}}$ Институт биологии и химии, Московский педагогический государственный университет, 119021 Москва, Россия

@E-mail: agatiatu@kpfu.ru

\begin{abstract}
Для пер-6-О-(трет-бутил)(дифенил)-силил- $\beta$-циклодекстрина была обнаружена метастабильная жидкая фаза, необычная для монопроизводных бета-цииклодекстрина при температуре окружающей среды. Также в твёрдом аморфном виде данное вещество может существовать как стабильное молекулярное стекло. В работе были определены условия и параметры фазовых переходов между кристаллической, стеклообразной и жидкой формой. Изученное вещество растворимо во множестве растворителей, кристаллизация из которых и из переохлажденного расплава приводит к образованию двух различных полиморфных модификаций. Жидкое монопроизводное бета-цииклодекстрина амфифильно, что даёт преимущество при использовании в растворах, чистом виде или даже в качестве растворителя для множества субстратов с различной структурой.
\end{abstract}

Ключевые слова: Циклодекстрин, силильное производное, полиморфизм, молекулярное стекло, термический анализ, рентгеновская порошковая дифрактометрия.

\section{Introduction}

Silylated cyclodextrin derivatives find their applications in amphiphilic trans-membrane transport, ${ }^{[1]}$ enantioselective catalysis, ${ }^{[2]}$ chiral recognition ${ }^{[3]}$ and as chiral stationary phase for gas chromatography. ${ }^{[4,5]}$ These compounds also can be used for further modifications of cyclodextrins. ${ }^{[6]}$ Silylated cyclodextrins may be also regarded for application in drug prolongation and delivery, where hydrophobic cyclodextrin derivatives are effective, like ethylated beta-cyclodextrin, which showed sustained release of drug in injectable oily suspensions. ${ }^{[7]}$ For these applications, liquid forms of 
cyclodextrins are the most essential because crystallization of host or host-drug complex is undesirable in biological systems. ${ }^{[8,9]}$ Nowadays, only a few cyclodextrin derivatives are known, which are liquid at room temperature. ${ }^{[10,11]}$ These lipophilic derivatives have all hydroxyls substituted with alkyl or acetyl groups and are used as nonvolatile liquid phase in chromatography. ${ }^{[10,11]}$

In this work, per-6-O-(tert-butyl)(diphenyl)silyl- $\beta$ cyclodextrin (1), Figure 1, was studied. This compound is a mono-derivative of $\beta$-cyclodextrin modified by primary face. Partially derivatized cyclodextrins with free hydroxyl groups are amphiphilic and have nanocapsule forming properties for drug delivery. ${ }^{[12]}$ The conditions of $\mathbf{1}$ existence in liquid form without decomposition and crystallization were determined in the present study. A liquid cyclodextrin derivative can be formulated with high concentration either in pure form or even as solvent, for example, instead of ionic liquids, ${ }^{[8]}$ toxicity of which is rather high and requires further investigation. ${ }^{[13,14]}$

Phase transitions between $\mathbf{1}$ crystal, glassy and liquid forms, including formation of polymorphs, were studied in this work. Such information on thermal and phase stability is necessary for any material used in pharmacy and other industrial fields, where cyclodextrins and their derivatives are widely presented. ${ }^{[15,16]}$

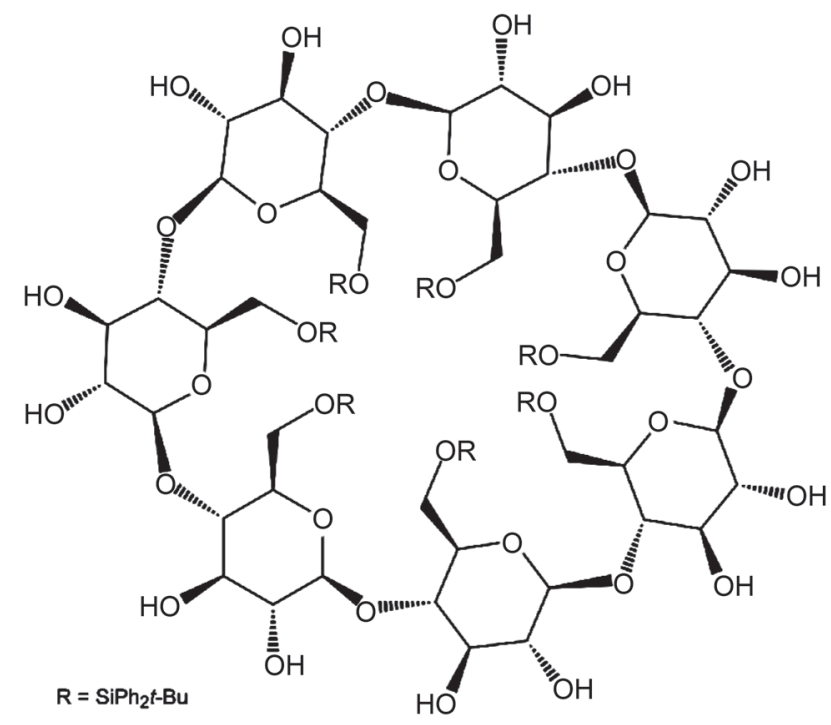

Figure 1. Per-6-O-(tert-butyl)(diphenyl)silyl- $\beta$-cyclodextrin (1).

\section{Experimental}

\section{Synthesis}

Per-6-O-(tert-butyl)(diphenyl)silyl- $\beta$-cyclodextrin was synthesized as described earlier. ${ }^{[17]}$ Obtained powder was dried at $100{ }^{\circ} \mathrm{C}$ for $8 \mathrm{~h}$ in vacuum of $100 \mathrm{~Pa}$ before experiments.

\section{Thermal Analysis}

Simultaneous TG/MS experiments were made using a thermoanalyzer Netzsch STA 449 C Jupiter coupled with quadrupole mass-spectrometer Netzsch QMS $403 \mathrm{C}$ Aeolos as described elsewhere. ${ }^{[18]}$ The temperature was scanned with a rate of $10 \mathrm{~K} / \mathrm{min}$, and isothermal mode at $250{ }^{\circ} \mathrm{C}$ for $20 \mathrm{~min}$ was added to thermal analysis, which was followed by further heating with 10 $\mathrm{K} / \mathrm{min}$ to $290^{\circ} \mathrm{C}$.

\section{Temperature-Modulated Differential Scanning Calorimetry}

Differential scanning calorimetry (DSC) studies were performed with Netzsch DSC 204 F1 Phoenix. ${ }^{[19]}$ A sample of $7 \mathrm{mg}$ was placed in a standard aluminum crucible $(40 \mu \mathrm{L})$ with lid having a hole with diameter of $0.5 \mathrm{~mm}$. The sample was cooled to $-85^{\circ} \mathrm{C}$ and then heated to $80^{\circ} \mathrm{C}$. The linear rate of change of temperature was $10 \mathrm{~K} / \mathrm{min}$. The heat flux was modulated on sinusoid with a period of 60 seconds and amplitude of $\pm 0.5 \mathrm{~K}$. All measurements were performed in a dynamic atmosphere of argon at a flow rate of $150 \mathrm{~mL} / \mathrm{min}$.

\section{X-Ray Powder Diffractograms}

XRPD data were obtained using Rigaku MiniFlex 600 diffractometer. In this experiment, $\mathrm{Cu} K \alpha$ radiation $(30 \mathrm{kV}, 10 \mathrm{~mA})$ was used, $K \beta$ radiation was eliminated with Ni filter, $K \alpha 2$ diffraction peaks were eliminated using Rigaku software. The diffractograms were determined at room temperature in the reflection mode, with scanning speed $5 \% \mathrm{~min}$. Clathrate samples were loaded into a glass holder. Patterns were recorded in the $2 \theta$ range between $3^{\circ}$ and $45^{\circ}$ without sample rotation. The most diffractograms were determined also with addition of standard silicon powder SRM 640d, and corresponding corrections were applied to $2 \theta$ values.

\section{Results and Discussion}

Thermal stability of $\mathbf{1}$ was studied using simultaneous TG/DSC/MS analysis, Figure 2. Studied compound is absolutely stable at temperature up to $117{ }^{\circ} \mathrm{C}$, and starts losing weight at higher temperatures. $5 \%$ and $10 \%$ of weight loss are observed at 194 and $213{ }^{\circ} \mathrm{C}$, respectively. Peaks on MS curves $\mathrm{m} / \mathrm{z}=52$ and 79 corresponding to some weight loss between 120 and $230{ }^{\circ} \mathrm{C}$ can be caused by traces of pyridine used for synthesis. ${ }^{[17]}$ Process of $\mathbf{1}$ thermal decomposition can be associated with endothermic DSC peak, corresponding onset temperature is $209^{\circ} \mathrm{C}$. The release of water matches to decomposition of a cyclodextrin macrocycle, and this process makes an appearance only at $280{ }^{\circ} \mathrm{C}$, according to $m / z=18 \mathrm{MS}$ curve, Figure 2. So, we can conclude that cyclodextrin macrocycle is stable up to $280{ }^{\circ} \mathrm{C}$ and significant weight loss started at $209^{\circ} \mathrm{C}$ can be explained by desilylation of $\mathbf{1}$.

The melting of 1 initial crystalline sample can be seen from sharp endothermic peak at $58{ }^{\circ} \mathrm{C}$, Figure 2. At this temperature, the initial powder transforms to the viscous liquid, which is stable at room temperature, Figure 3a,b. Contact of the obtained liquid form with a small crystalline fragment of $\mathbf{1}$ initiates its crystallization, Figure 3c.

Detailed study of phase transitions of initially crystalline 1 was conducted using cyclic DSC experiment. Crystalline sample of 1 was heated up to $80^{\circ} \mathrm{C}$, then cooled to $-85^{\circ} \mathrm{C}$, and heated to $80^{\circ} \mathrm{C}$. Cycle of cooling and heating was then reiterated. DSC curves of the first, second and third heating processes are shown in Figure 4a-c, curves of the first and second cooling processes are shown in Figure 4d,e.

The fusion of $\mathbf{1}$ can be seen from two endothermic DSC peaks at $51{ }^{\circ} \mathrm{C}$ and $59^{\circ} \mathrm{C}$, Figure $4 \mathrm{a}$. The fusion enthalpy is 


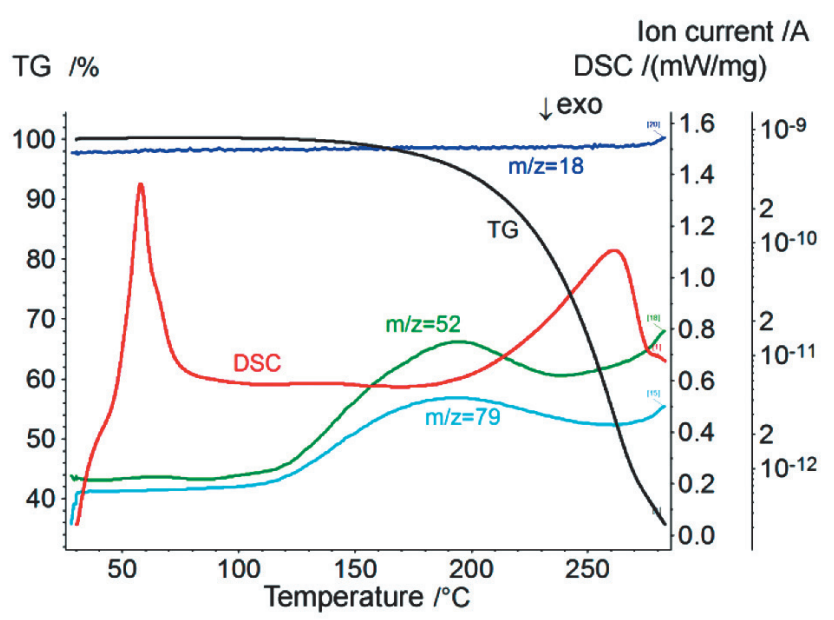

Figure 2. TG/DSC/MS curves for sample 1 crystallized from pyridine and dried in vacuum at $100{ }^{\circ} \mathrm{C}$.

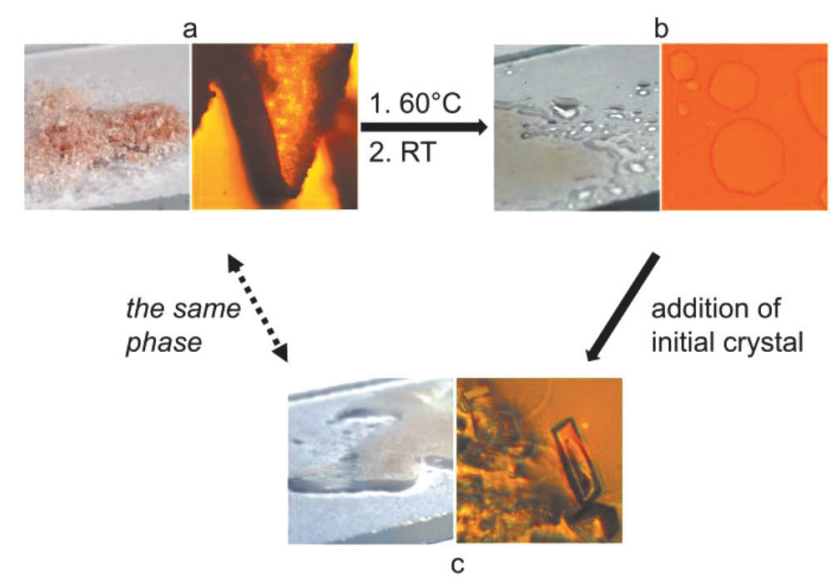

Figure 3. (a) Initial crystals of 1. (b) Metastable liquid prepared by melting of initial crystals and cooled to room temperature. (c) Recrystallized sample prepared by addition of initial crystal of $\mathbf{1}$ to its metastable liquid form.

$48.06 \mathrm{~J} \cdot \mathrm{g}^{-1}$, or $134.6 \mathrm{~kJ} / \mathrm{mol}$. We can suppose that main peak at $51{ }^{\circ} \mathrm{C}$ corresponds to the melting of major crystalline form. The second DSC peak at $59^{\circ} \mathrm{C}$ may correspond to the melting of second polymorph, which exists in the sample.

DSC analysis confirms the stability of $\mathbf{1}$ in amorphous form. There are no melting peaks at 51 and $60{ }^{\circ} \mathrm{C}$ in the second and third heating curves, Figure $4 \mathrm{~b}, \mathrm{c}$. In cooling curves, Figure 4 d,e, glass transition is observed at $-12{ }^{\circ} \mathrm{C}$ and $-9^{\circ} \mathrm{C}$ with corresponding $\Delta C_{p} 0.499$ and $0.507 \mathrm{~J} \cdot \mathrm{g}^{-1} \cdot \mathrm{K}^{-1}$. At heating, glass transition is observed at $-8{ }^{\circ} \mathrm{C}$, Figure $4 \mathrm{~b}$,c, with corresponding $\Delta C_{p}=0.494 \mathrm{~J} \cdot \mathrm{g}^{-1} \cdot \mathrm{K}^{-1}$. Close values of a heat capacity change at cooling and heating show no aging processes during the studied thermal cycles. Obtained values are rather high, being several times more than $\Delta C_{p}$ obtained earlier for a glass transition in calixarenes. ${ }^{[20,21]}$

Exposure of liquid $\mathbf{1}$ to the vapors of methanol, ethanol, 1-propanol, acetonitrile, benzene and toluene results in a quick formation of solution, so, $\mathbf{1}$ can be mixed with these solvents in any proportion. For comparison,
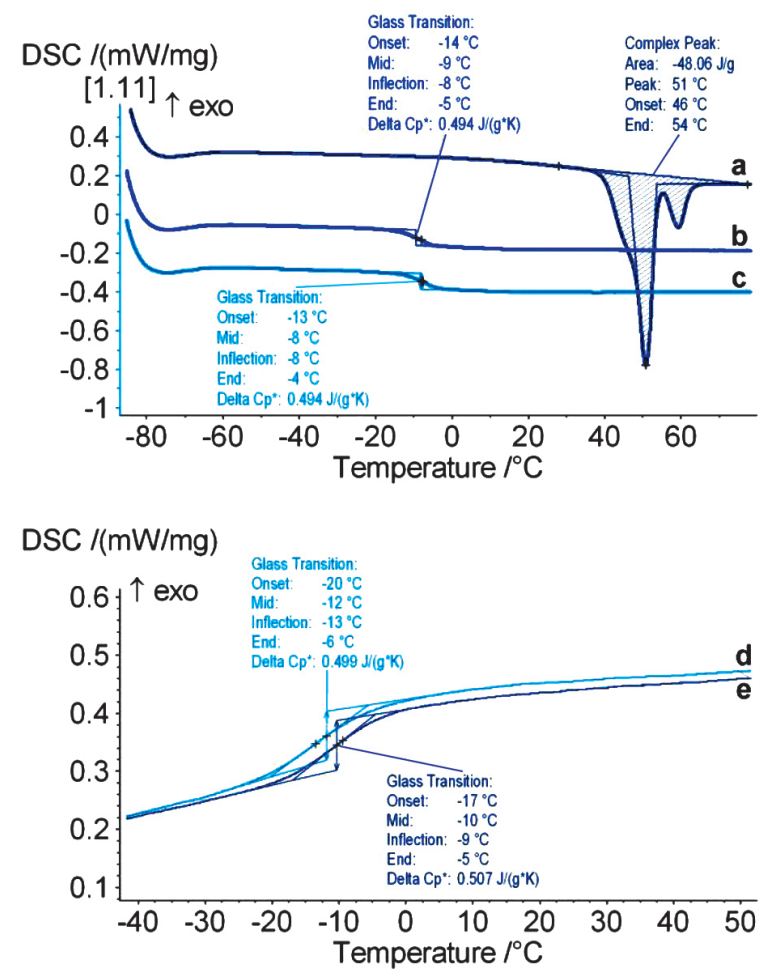

Figure 4. Curves of cyclic DSC experiment for initially crystalline $\mathbf{1}$ at heating $(\mathrm{a}, \mathrm{b}, \mathrm{c})$ and cooling $(\mathrm{d}, \mathrm{e})$.

natural beta-cyclodextrin forms solid clathrates under the same conditions. ${ }^{[2]}$ Evaporation of solvents from prepared solutions leads to crystallization of $\mathbf{1}$ to different polymorphs studied by XRPD, Figure 5. Cyclodextrin 1 has a moderate solubility in water near $1 \mathrm{~g} \cdot \mathrm{L}$. So, water is not a good solvent for recrystallization.

Two steps of melting process may be explained by a presence of two polymorphs in the sample. To verify this assumption, XRPD analysis of the sample was used. One can see a halo in $\mathbf{1}$ powder diffractogram, Figure 5a, which can indicate the presence of an amorphous phase in the sample. The diffractogram of the solid $\mathbf{1}$ prepared by crystallization of its metastable liquid by addition of the initial crystalline powder is shown in Figure 5b. It is essentially different from the diffractogram of the initial sample, Figure 5a. So, this crystallization process gives a new polymorph.

Crystallization of $\mathbf{1}$ from its solutions results in formation of crystals with a smaller halo in diffractograms, Figure 5c-h, which can be caused by a higher freedom of $\mathbf{1}$ molecules in solution. On the contrary, the crystallization of pure viscous liquid $\mathbf{1}$ may have diffusion problems giving a larger content of its amorphous component. So, recrystallization of $\mathbf{1}$ from solution may allow obtaining a purer sample with the lower contents of other polymorphs and amorphous phase.

Diffractograms of 1 recrystallized from its solutions in methanol, ethanol, 1-propanol and acetonitrile (Figure 5e-h) are very close to each other and to the initial sample prepared from pyridine (Figure 5b). Samples recrystallized from benzene and toluene have diffractograms different from those of samples crystallized from the other studied solvents, with large peaks in the region of $10-13.5^{\circ}$, Figure 


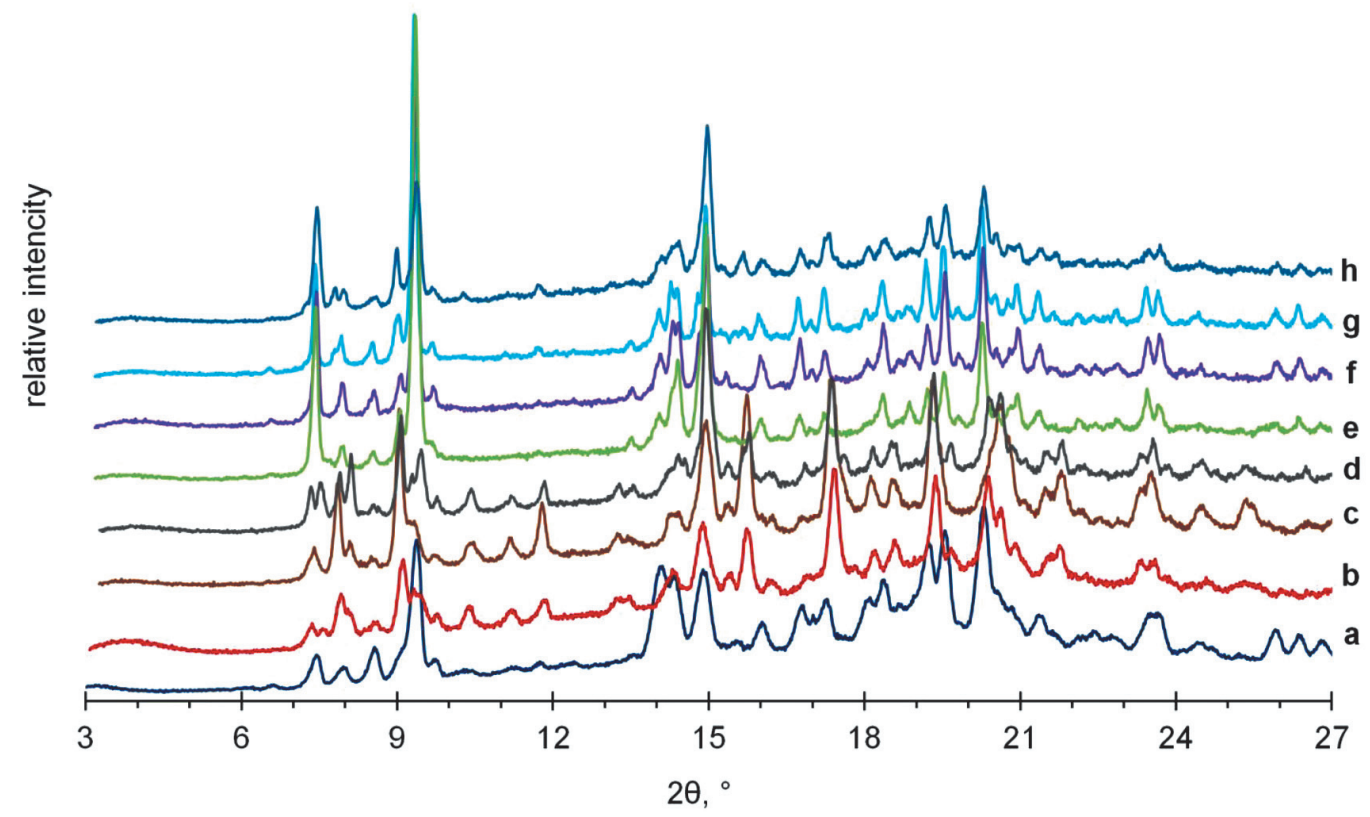

Figure 5. X-Ray powder diffractograms of samples 1: (a) initial crystalline powder prepared in pyridine; recrystallized 1: (b) from its liquid form by addition of the initial crystal; (c) from toluene; (d) from benzene; (e) from methanol; (f) from ethanol; (g) from 1-propanol; (h) from acetonitrile.

$5 \mathrm{c}, \mathrm{d}$, which are absent in diffractograms of crystals grown from the studied hydrophilic solvents. One can see that the crystallized melt and samples crystallized from benzene and toluene have diffractograms close to each other, Figure $5 \mathrm{~b}-\mathrm{d}$. We can suggest that crystallization of pure $\mathbf{1}$ liquid by addition of the initial crystals results in formation of the same polymorph as prepared by crystallization of $\mathbf{1}$ from its solutions in benzene and toluene.

The studied silyl beta-cyclodextrin derivative $\mathbf{1}$ can exist in crystalline and liquid state stable at room temperature. Such behavior is uncommon for cyclodextrin mono-derivatives, which are mostly crystalline. ${ }^{[23]}$ Liquid state of $\mathbf{1}$ is stable between glass transition at $-9^{\circ} \mathrm{C}$ and thermal decomposition at $117{ }^{\circ} \mathrm{C}$. A liquid cyclodextrin derivative can be interesting as unusual receptor or liquid crystal system as it was shown before for thio derivatives of cyclodextrin. ${ }^{[24]}$

\section{Conclusions}

The studied monosubstituted per-6-O-(tert-butyl) (diphenyl)silyl- $\beta$-cyclodextrin was found to exist as a stable liquid in a wide range of temperatures and in two polymorphic forms. Fusion enthalpy of the initial crystalline form prepared from solution in pyridine and heat capacity change at glass transition of the over cooled melt were determined. Conditions of existence for the crystalline, glassy and liquid forms were found. The studied compound can be mixed in any proportion with a number of hydrophilic and lipophilic solvents and has moderate solubility in water. Crystallization of the studied compound from hydrophilic solvents methanol, ethanol, 1-propanol and acetonitrile leads to formation of the same polymorph as the ini- tial one prepared from the cyclodextrin solution in pyridine. Crystallization from hydrophobic solvents benzene and toluene results in formation of the second polymorph, which is close to the sample prepared by crystallization of liquid form by an additive of the initial crystalline powder. Being amphiphilic, the studied liquid mono-derivative of beta-cyclodextrin is preferable for applications in solutions, in pure form or even as a solvent for substrates with great structural variety.

Acknowledgements. The work was supported by Russian Government Program of Competitive Growth of Kazan Federal University and by RFBR, grant No. 17-03-01311. The equipment of Federal Center of Shared Equipment of Kazan Federal University was used in this work.

\section{References}

1. József S. Chem. Rev. 1998, 98, 1743-1754.

2. Asahara H., Kida T., Iwamoto T., Hinoue T., Akashi M. Tetrahedron 2014, 70, 197-203.

3. Kida T., Iwamoto T., Asahara H., Hinoue T., Akashi M. J. Am. Chem. Soc. 2013, 135, 3371-3374.

4. Blum W., Aichholz R. J. High. Resolut. Chromatogr. 1990, 13, 515-518.

5. Maas B., Dietrich A., Karl V., Kaunzinger A., Lemann D., Köpke T., Mosandl A. J. Microcolumn Sep. 1993, 5, 421-427.

6. Khan A. R., Forgo P., Stine K. J., D'Souza V. T. Chem. Rev. 1998, 98, 1977-1996.

7. Uekama K., Hirayama F., Irie T. Chem. Rev. 1998, 98, 20452076.

8. Marrucho I.M., Branco L.C., Rebelo L.P.N. Annu. Rev. Chem. Biomol. Eng. 2014, 5, 527-546.

9. Hadgraft J., Lane M.E. Expert Opin. Drug. Deliv. 2016, 13(6), $1-35$. 
10. Li W.-Y., Jin H.L., Armstrong D.W. J. Chromatogr. 1990, 509, 303-324.

11. Armstrong D.W., Li W., Chang C.-D. Anal. Chem. 1990, 62, 914-923.

12. Memişoğlu E., Bochot A., Şen M., Charon D., Duchêne D., Hincal A.A. J. Pharm. Sci. 2002, 91, 1214-1224.

13. Phama T.P.T., Choa C.-W., Yun Y.-S. Water Research 2010, 44, 352-372.

14. Zhao Y., Zhao J., Huang Y., Zhou Q., Zhang X., Zhang S. J. Hazard. Mater. 2014, 278, 320-329.

15. Bettinetti G., Novák Cs., Sorrenti M. J. Therm. Anal. Calorim. 2002, 517-529.

16. Veiga M.D., Merino M., Fernández D., Lozano R. J. Therm. Anal. Calorim. 2002, 68, 511-516.

17. Kurochkina G.I., Popkov A.V., Levina I.I., Grachev M.K. Russ. J. Gen. Chem. 2016, 86, 317-320.
18. Yakimova L.S., Ziganshin M.A., Sidorov V.A., Kovalev V. V., Shokova E.A., Tafeenko V.A., Gorbatchuk V.V. J. Phys. Chem. $B$ 2008, 112, 15569-15575.

19. Ziganshin M.A., Bikmukhametova A.A., Gerasimov A.V., Gorbatchuk V.V., Ziganshina S.A., Bukharaev A.A. Prot. Met. Phys. Chem. Surf. 2014, 50, 49-54.

20. Gataullina K.V., Ziganshin M.A., Stoikov I.I., Gubaidullin A.T., Gorbatchuk V.V. Phys. Chem. Chem. Phys. 2015, 17, 15887-15895.

21. Ashram M., Al-Ghezawi N., Awaad I.A., Asman G. Turk. J. Chem. 2009, 33, 647-656.

22. Gatiatulin A.K., Ziganshin M.A., Yumaeva G.F., Gubaidullin A.T., Suwinska K., Gorbatchuk V.V. RSC Adv. 2016, 6, 61984-61995.

23. Szejtli J. J. Mater. Chem. 1997, 7, 575-587.

24. Ling C.-C., Darcy R., Risse W. J. Chem. Soc., Chem. Commun. 1993, 438-440. 